Article

\title{
A Cost-Efficient Method for Unsymmetrical Meso-Aryl Porphyrin Synthesis Using NaY Zeolite as an Inorganic Acid Catalyst
}

\author{
Mário J. F. Calvete *, Lucas D. Dias, César A. Henriques, Sara M. A. Pinto, Rui M. B. Carrilho \\ and Mariette M. Pereira * \\ Coimbra Chemistry Centre, CQC, Departamento de Química, Faculdade de Ciências e Tecnologia da \\ Universidade de Coimbra, Rua Larga, 3004-535 Coimbra, Portugal; lucasdanillodias@gmail.com (L.D.D.); \\ c.henriques@qui.uc.pt (C.A.H.); smpinto@qui.uc.pt (S.M.A.P.); rui.carrilho@uc.pt (R.M.B.C.) \\ * Correspondence: mcalvete@qui.uc.pt (M.J.F.C.); mmpereira@qui.uc.pt (M.M.P.); \\ Tel.: +351-966-174-744 (M.J.F.C.); +351-239-854-474 (M.M.P.)
}

Academic Editors: Michael Hanack, Augusto C. Tomé and João Paulo C. Tomé Received: 7 April 2017; Accepted: 2 May 2017; Published: 5 May 2017

\begin{abstract}
Herein we report the synthesis of unsymmetrical meso-aryl substituted porphyrins, using $\mathrm{NaY}$ zeolite as an inorganic acid catalyst. A comparative study between this method and the several synthetic strategies available in the literature was carried out. Our method presented a better, more cost-efficient rationale and displayed a significantly lower environmental impact. Furthermore, it was possible to verify the scalability of the process as well as the reutilization of the inorganic catalyst $\mathrm{NaY}$ (up to 6 times) without significant yield decrease. In addition, this method was applied to the synthesis of several other unsymmetrical porphyrins, from a low melting point porphyrin to mono-carboxylated halogenated unsymmetrical porphyrins, in yields higher than those found in the literature. Additionally, for the first time, two acetamide functionalized halogenated porphyrins were prepared in high yields. This methodology opens the way to the preparation of high yielding functionalized porphyrins, which can be easily immobilized for a variety of applications, either in catalysis or in biomedicine.
\end{abstract}

Keywords: unsymmetrical porphyrins; inorganic acid catalysis; alternative synthetic methodologies

\section{Introduction}

Owing to porphyrin's myriad of applications, including biomedicine [1-8], catalysis [9-12], and materials [13-18], the preparation of unsymmetrically substituted porphyrins, bearing bridgeable groups for further linkage to other chemical entities and materials, is of utmost interest [19-26]. Unsymmetrically substituted porphyrin design has been applied for several decades, at first, using porphyrin $\beta$-pyrrolic substituting patterns such as the $3+1$ route [27-29], employing the chemistry proposed in the well-known MacDonald 2+2 method [30], which essentially relied on the cumbersome synthesis of tripyrranes [31], later mitigated by Sessler's advances on their syntheses [32]. Despite all progress [33,34], over the last decade, porphyrin scientists have turned their attention to the preparation of meso-patterned unsymmetrical porphyrins, mostly given to their more amenable syntheses [35-39], but still presenting a high number of steps in their methodologies (low overall yields), despite their lower need of purification procedures. Nevertheless, classical methods are the most used for synthesizing the commonly denominated $\mathrm{A}_{3} \mathrm{~B}$-meso-patterned porphyrins, which rely on mixed aldehyde condensation in a 3:1 proportion (hence $A_{3} B$ ) with four equivalents of pyrrole. Under the specific conditions of each method, this approach produces a statistical mixture of products that have to be further separated from the desired compound; enough reason to assume the imperative necessity 
to develop cost-efficient methods for the preparation of unsymmetrically substituted porphyrins on a larger scale.

Hence, the development of profitable synthetic methodologies for the preparation of porphyrins bearing at least one bridgeable chemical group, concomitantly with other property-enhancing groups, is presumably one of the main aims in synthetic porphyrin chemistry at present.

Herein, we expand the scope and demonstrate the versatility of our recent synthetic method, which uses a porous solid inorganic acid (zeolite $\mathrm{NaY}$ ) as catalyst [40-42] to promote the cyclization of pyrrole with a series of aromatic aldehydes, bearing electron donating or withdrawing substituents, portraying a highly improved yield synthesis of several unsymmetrical meso-aryl substituted porphyrins, some of them for the first time. We also discuss the features of this new methodology for the preparation of unsymmetrical meso-aryl porphyrins from an ecological and economical point of view, which are crucial aspects when choosing a methodology for the preparation of such key synthons, with a multitude of applications.

\section{Results and Discussion}

\subsection{Synthesis and Characterization of Unsymmetrically Substituted Porphyrins}

It is well established that the pKa and the type of acid (organic [43-45] or solid [46,47]—Lewis or Brønsted) are determining factors for efficient pyrrole and aldehyde condensation. Using acids as catalysts, the current methods for meso-aryl substituted porphyrin syntheses include the classical one-pot Adler-Longo [43] and Gonsalves-Pereira [44] strategies and the two-step Lindsey method [45], along with more recent microwave irradiation methodologies [48-52].

Following our previously reported method, where NaY was used as a porous solid acid catalyst [40], and since the legitimate establishment of any porphyrin synthetic methodology implies the demonstration of its flexibility and general usability, we established first a direct correlation between applied methodologies and the yields of desired compounds.

Therefore, we carried out the preparation of 5-(4-hydroxyphenyl)-10,15,20-tris(phenyl) porphyrin (1) $[8,17,23,53]$ as the model unsymmetrical meso-aryl porphyrin using the three best established methods against our herein disclosed methodology (Table 1). For the sake of comparison, we scrupulously followed the literature-described reaction conditions of Adler-Longo [43], Gonsalves-Pereira [44], and Lindsey [45] methods (see Supplementary Materials—Section S3).

Table 1. Comparative study for the synthesis of 5-(4-hydroxyphenyl)-10,15,20-tris(phenyl) porphyrin (1) using Adler-Longo, Gonsalves-Pereira, Lindsey, and "NaY" methods.

\begin{tabular}{ccccc}
\hline Method & Reagents (exc. aldehydes and pyrrole) & Temperature & Concentration (M) & Yield (\%) \\
\hline Adler-Longo & propionic acid & $140{ }^{\circ} \mathrm{C}$ & 0.30 & 6 \\
\hline Gonsalves-Pereira & acetic acid/nitrobenzene & $130{ }^{\circ} \mathrm{C}$ & 0.40 & 7 \\
\hline Lindsey & $\begin{array}{c}\text { dichlorome } \\
\text { thanetrifluoroacetic acid } \\
\text { DDQ/triethylamine }\end{array}$ & $25{ }^{\circ} \mathrm{C}$, then $45^{\circ} \mathrm{C}$ & 0.03 & 15 \\
\hline This work & $\begin{array}{c}\text { acetic acid/nitrobenzene } \\
\text { NaY zeolite }\end{array}$ & $130{ }^{\circ} \mathrm{C}$ & 0.42 & 16 \\
\hline
\end{tabular}

For our "NaY" method [40], in a typical experiment, 0.016 molar equivalents of NaY were added to 3 molar equivalents of benzaldehyde, 1 molar equivalent of 4-hydroxybenzaldehyde, and 4 molar equivalents of pyrrole mixed in glacial acetic acid and nitrobenzene (7:5) in a 0.42 molar concentration. The reaction mixture was heated at $130{ }^{\circ} \mathrm{C}$ for ca. $2 \mathrm{~h}$ (Scheme 1). After an experimental workup, which included column chromatography using silica as a stationary phase, the title compound $\mathbf{1}$ was isolated in 16\% yield (see Material and Methods and Supplementary Materials-Section S3 for details). 

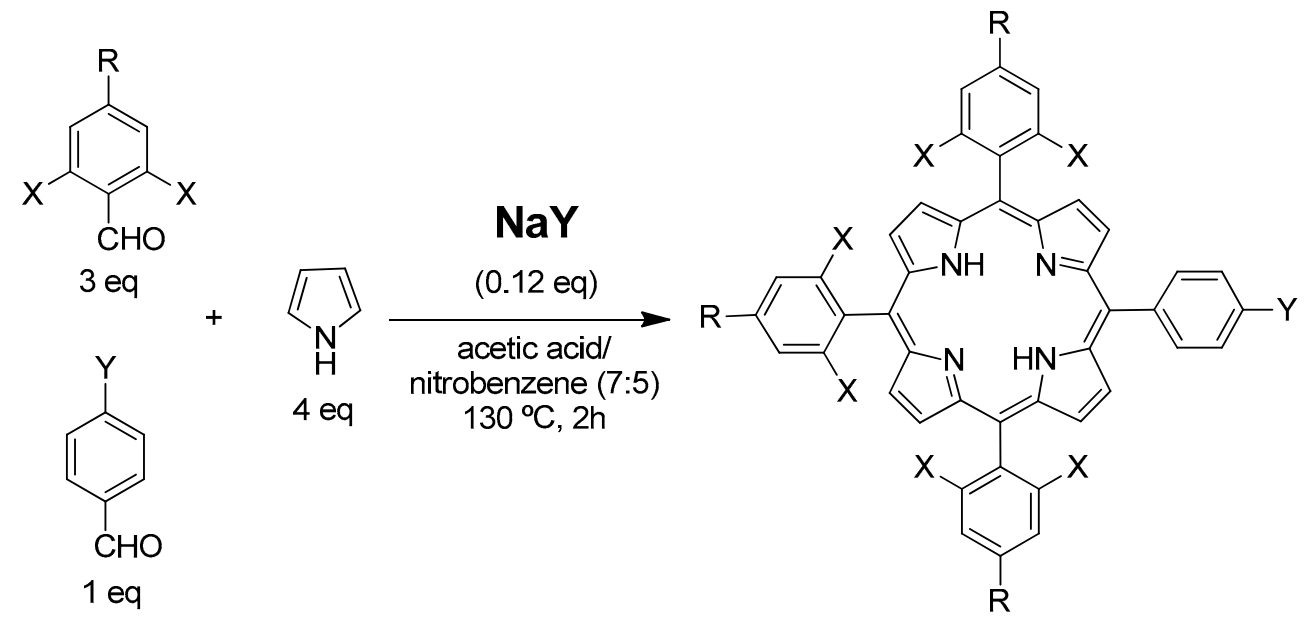

$$
\begin{aligned}
& \text { 1: } X=\mathrm{H} ; Y=\mathrm{OH} ; \mathrm{R}=\mathrm{H}(16 \%) \\
& \text { 2: } \mathrm{X}=\mathrm{H} ; \mathrm{Y}=\mathrm{OH} ; \mathrm{R}=\mathrm{O}-(2 \text {-ethylhexyl) }(15 \%) \\
& \text { 3: } \mathrm{X}=\mathrm{H} ; \mathrm{Y}=\mathrm{COOH} ; \mathrm{R}=\mathrm{H}(17 \%) \\
& \text { 4: } \mathrm{X}=\mathrm{F} ; \mathrm{Y}=\mathrm{COOH} ; \mathrm{R}=\mathrm{H}(13 \%) \\
& \text { 5: } \mathrm{X}=\mathrm{F} ; \mathrm{Y}=\mathrm{NHAc} ; \mathrm{R}=\mathrm{H}(17 \%) \\
& \text { 6: } \mathrm{X}=\mathrm{Cl} ; \mathrm{Y}=\mathrm{NHAc} ; \mathrm{R}=\mathrm{H}(13 \%)
\end{aligned}
$$

Scheme 1. Synthesis of unsymmetrical meso-aryl substituted porphyrins, using NaY zeolite as an inorganic acid catalyst.

Analysis of Table 1 shows that using the Adler-Longo or Gonsalves-Pereira methods, the yields for obtaining porphyrin 1 are quite similar (6 and 7\% yields, respectively). The main difference between these two strategies resides in that, using the Adler-Longo method, the yield is overestimated by the contamination with the corresponding chlorin (around 10-15\%, by UV-Vis checking), which could be further oxidized to its correpsonding porphyrin, but was out of the scope in this study. On the other hand, the Gonsalves-Pereira method permitted the isolation of porphyrin 1 with high purity, without chlorin contamination, in a slightly higher yield. Lindsey methodology provided the desired compound in $15 \%$ yield, but using quite diluted reaction conditions $(0.03 \mathrm{M})$ and the expensive DDQ oxidant, involving two steps, while our methodology, which uses $\mathrm{NaY}$ as co-catalyst, provided the same compound in $16 \%$ yield, using concentrations of $0.42 \mathrm{M}$ and a simpler procedure. In our case, the reaction of pyrrole and aldehydes, using a mixture of acetic acid and nitrobenzene as a solvent (acetic acid works also as catalyst and nitrobenzene as the oxidant), in the presence of porous solid $\mathrm{NaY}$ zeolite in ca. $3.2 \mathrm{~mol} \%$, as co-catalyst, enhanced yield of the desired unsymmetrical meso-aryl substituted porphyrin 1 . Lewis acidity values were calculated for $\mathrm{NaY}$ by the pyridine (Py) adsorption method, followed by infrared spectroscopy, giving a value of $520 \mathrm{mmol}$ Py per $\mathrm{g}$ of $\mathrm{NaY}$ (see Supplementary Materials-Section S2), which attests its high capacity to act as a Lewis acid in the reaction condensation between pyrrole and aldehydes. It is worth mentioning that the ratio between $\mathrm{NaY}$ and all reagents (pyrrole and aldehydes (3.2 mol \%) (assuming NaY MW = 12,752 g/mol) [54] was established after tests using different ratios (Figure 1 and Supplementary Materials-Section S2).

When a $2.1 \mathrm{~mol} \% \mathrm{NaY}$ was used, the yield of porphyrin 1 was $11 \%$, while a yield of $16 \%$ was obtained when the ratio was increased to $4.3 \mathrm{~mol} \%$, identical to the yield obtained, when a $3.2 \mathrm{~mol} \%$ amount of NaY was used. Therefore, it was demonstrated that the condensation reaction in the presence of porous solid $\mathrm{NaY}$ zeolite as a co-catalyst at ca. $3.2 \mathrm{~mol} \%$ held the best proportion from a cost-efficiency point of view. Moreover, it should be mentioned that this synthesis was easily scalable from 2.5 to $100 \mathrm{mmol}$ (based on pyrrole), without any appreciable drop on the overall yield, demonstrating the high scalability of the method (see Supplementary Materials-Section S4). 


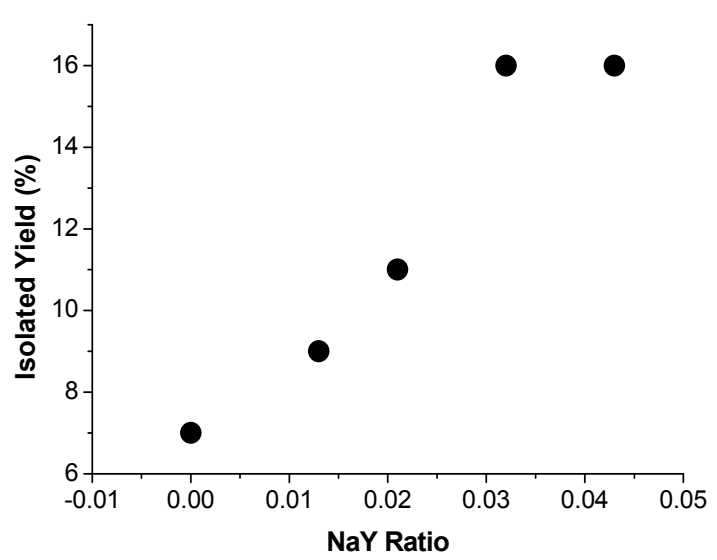

Figure 1. Isolated yields of Porphyrin 1 vs. the NaY amount. Note: when NaY ratio $=0$, it represents the isolated yields using the Gonsalves-Pereira method.

However, the application of this method as a real practical alternative for the synthesis of unsymmetrical porphyrins requires the validation of $\mathrm{NaY}$ as a reusable catalyst. This was accomplished by evaluating its reutilization in the synthesis of Porphyrin 1 (Figure 2) (see Supplementary MaterialsSection S5).

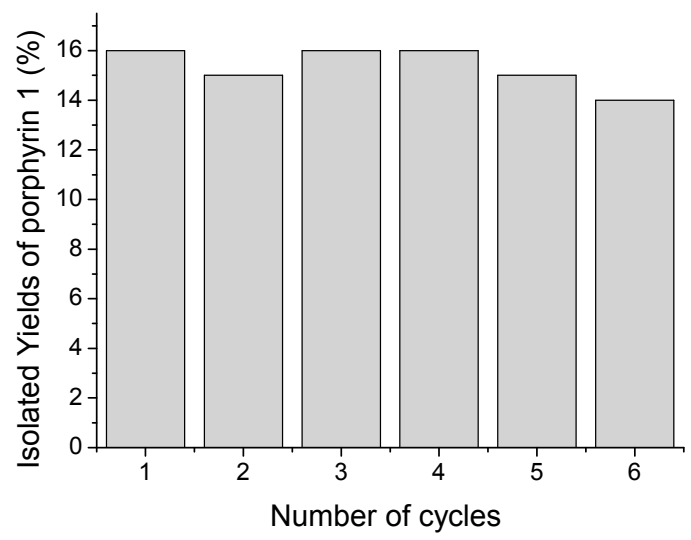

Figure 2. Reutilization of $\mathrm{NaY}$ on the synthesis of Porphyrin 1.

After the first cycle, the NaY catalyst was collected by filtration and washed with dichloromethane and tetrahydrofuran, followed by drying of the solid overnight, at $150{ }^{\circ} \mathrm{C}$ under vacuum. The subsequent cycles were carried out with the recovered solid and reactivation procedure was similar for each reutilization. We also carried out a reutilization experiment where the catalyst was used without prior reactivation, yielding Porphyrin 1 in a 9\% yield, similar to that obtained using the Gonsalves-Pereira method alone (7\%). This observation suggests that NaY voids are mainly occupied by organic materials, which may block the catalyst's acid sites.

\subsection{The Determination of Method's Sustainability and Cost-Efficiency}

Reaction efficiency is a very important issue, but ecological impact also plays a key role when designing more sustainable synthetic methodologies. Therefore, metrics that have been developed to judge synthetic efficiency must be used [55]. An important parameter is the environment factor (E Factor), which represents the ratio between the weight of waste generated and the total weight of the end product $[56,57]$. We analyzed several established methodologies for the preparation of 5-(4-hydroxyphenyl)-10,15,20-tris(phenyl) porphyrin (1), obtaining approximate E Factor values for each method (see Table 2 and Supplementary Materials-Section S6). The calculation of E Factors was 
carried out considering the production of $10 \mathrm{mmol}$ of Porphyrin 1, i.e., $6.3 \mathrm{~g}$. To obtain this amount of end product, we correlated the yield obtained for each reaction with each solvent/reagent used.

Table 2. Calculated E Factors and price for preparation of Porphyrin $\mathbf{1}^{\mathrm{a}}$.

\begin{tabular}{|c|c|c|c|c|}
\hline Method & E Factor & Price $(10 \mathrm{mmol})$ & Price $(10 \mathrm{mmol})^{b}$ & Price $(g)$ \\
\hline Adler-Longo & 6793 & $1068 €$ & $652 €$ & $103 €$ \\
\hline Gonsalves-Pereira & 4233 & $1011 €$ & $741 €$ & $118 €$ \\
\hline Lindsey & 7090 & $2002 €$ & $995 €$ & $158 €$ \\
\hline $\mathrm{NaY}$ & 2350 & $750 €$ & $504 €$ & $80 €$ \\
\hline
\end{tabular}

a Prices do not reflect reagents/solvents acquisitions on a large scale, but at a laboratory scale, using a well-established chemical company website prices. ${ }^{b}$ Considering solvent reutilization (non-mixed reaction and chromatography solvents)

Looking at E Factors, it is clear that the two-step Lindsey methodology is a higher waste-producer, expectable from the inherent high dilution requirements (E Factor $=7090$ ), while reactions using a high reagent concentration hold a lower E Factor (Table 2). It must be noted that, in a report by Lindsey and co-workers [58], where high concentration conditions were employed, an E factor of 2750 was calculated (see Supplementary Materials), demonstrating the importance of concentration in the waste production of such type of reactions. Considering the production of waste, our NaY method exhibits an E Factor of 2350, a lower value than those presented by the other methods, validating the reduction of solvents used and causing an improvement in the relative eco-friendliness of the method regarding waste production. However, it should be noted that a very significant cost of waste disposal is the cost of the disposal of silica, which is used in considerable amounts in statistical methodologies. Considering the approximations taken for the E Factor, we calculated, at current market prices, the cost of the production of $10 \mathrm{mmol}$ of Porphyrin $\mathbf{1}$ (Table 2), in order to account for the cost-efficiency of our methodology. We point out that the cost of labor, which is often a determining factor in choosing a scale-up procedure, is not evaluated here since it is similar for all statistical procedures and would similarly affect all methods. When designing a potential scale-up process, one must consider, when possible, the reutilization of solvents, particularly when used as pure solvents, not mixtures. Considering the reutilization of reaction and chromatography solvents, along with catalysts, the comparison of costs among the various methods changed considerably, as Lindsey's method prices reduced to less than half, for instance. Price analysis proves that the "NaY method," when compared to the other methodologies, is the most suitable method for the production of assessable quantities of Porphyrin 1, with a substantially favorable cost-to-efficiency ratio of $504 €$ per 10 mmol porphyrin (6.3 g), i.e., $80 €$ per gram (see Supplementary Materials-Section S7).

\subsection{Scope}

Having in hand a methodology displaying a cost-efficient feature, we hypothesized that extrapolation to the preparation of other unsymmetrical meso-aryl substituted porphyrins could be achieved. Thus, we extended the application of the NaY method to the preparation of Porphyrins 2-6 (Scheme 1) (see Supplementary Materials-Section S8).

Considering our interest in highly soluble low melting point porphyrins [41,52], we prepared 5-(4-hydroxyphenyl)-10,15,20-tris(4-ethylhexyloxyphenyl) porphyrin (2) in 15\% yield, higher than the previously reported using other methodologies (7-10\%) [41]. Similarly, and considering the high importance of monocarboxylic acid-substituted porphyrins for further functionalization, 5-(4-carboxyphenyl)-10,15,20-tris(phenyl) porphyrin (3) was also prepared in 17\% yield in just one step, while a careful literature search revealed that the best yields are usually obtained by first preparing the 5-(4-methoxycarbonylphenyl)-10,15,20-tris(phenyl) porphyrin, followed by ester hydrolysis, attaining 6.5\% overall yields [59]. Additionally, the 5-(4-carboxyphenyl)-10,15,20-tris(2,6-difluorophenyl) porphyrin (4) was prepared in $13 \%$ yield, in a single step in a yield comparable to the literature 
(16\%) [60], albeit obtained in a much higher amount when compared with the highly diluted Lindsey two-step procedure used, plus the deprotection of the corresponding methyl ester. Therefore, our method was revealed to be cost-efficient for the preparation of the above meso-monocarboxylphenyl substituted porphyrins using a one-step procedure, in yields comparable to those reported in the literature with obvious economical saving and environmental gain.

Finally, our herein described methodology afforded the new unsymmetrical meso-substituted mono-acetamide porphyrins 5 and $\mathbf{6}$. Following our particular interest on the synthesis of bioconjugated ${ }^{19} \mathrm{~F}-\mathrm{NMR}$ probes for biomedicinal applications, [61-63], for the first time, 5-(4-acetylaminophenyl)10,15,20-tris(2,6-difluorophenyl) porphyrin (5) was prepared, in 16\% yield. Likewise, aiming at the preparation of covalently immobilized catalysts, and bearing in mind the outstanding properties of halogenated porphyrins as oxidation catalysts $[9,64,65]$, our synthetic methodology was also applied to prepare, for the first time, 5-(4-acetylaminophenyl)-10,15,20-tris(2,6-dichlorophenyl) porphyrin (6) in $13 \%$ yield. These results are promising considering the low yields usually obtained in the synthesis of sterically hindered porphyrins through the condensation of 2,3-disubstituted benzaldehydes and pyrrole.

\section{Materials and Methods}

Commercially available reagents were purchased from Sigma-Aldrich (Lisbon, Portugal), Fluorochem (Derbyshire, UK) and Acros (Santo Antão do Tojal, Portugal), being used as received. Zeolite NaY was purchased from Zeolyst (Groningen, The Netherlands). All solvents were pre-dried according to standard laboratory techniques. All spectroscopic data from known porphyrins were confirmed $\left({ }^{1} \mathrm{H}-\mathrm{NMR}\right.$ and UV-Vis) and agree with the literature. UV-visible absorption spectra were recorded on a Hitachi U-2010 (Hitachi Corporation, Tokyo, Japan) using quartz cells. The molar absorption coefficients were determined using toluene as a solvent. Zeolite acidity measurements were performed using pyridine as probe molecule, followed by infrared spectroscopy (FTIR); a Nicolet Nexus spectrometer (GMI Inc., Ramsey, MN, USA) was used for the purpose. ${ }^{1} \mathrm{H}-\mathrm{NMR}$ spectra were recorded on a $400 \mathrm{MHz}$ Brucker-Amx (Bruker, Karlsruhe, Germany). The chemical shifts are given in parts per million (ppm) relative to tetramethylsilane at $\delta 0.00 \mathrm{ppm}$ for proton spectra. Mass spectra were acquired using an Applied Biosystems Voyager DE-STR instrument (Applied Biosystems, Foster City, CA, USA) equipped with a nitrogen laser $(\lambda=337 \mathrm{~nm})$ or Bruker microTOFQ instrument (Bruker, Madrid, Spain) by Unidade de Espectrometría de Masas e Proteómica, Universidade de Santiago de Compostela, Spain. Column chromatographies were performed with silica gel grade 60, 70-230 mesh as a stationary phase.

Details of the synthetic procedures employed in the synthesis of Porphyrins 1-6 are described in Supplementary Materials. The synthetic procedure for a typical experimental using the "NaY method" is described below.

\subsection{General Procedure}

One gram of $\mathrm{NaY}$ zeolite $(0.08 \mathrm{mmol})$ was placed into a $50 \mathrm{~mL}$ round flask, containing a 1:3 mixture of aldehydes (0.625:1.875 mmol), in a glacial acetic acid/nitrobenzene mixture $(7 / 5 \mathrm{~mL})$. An addition of equimolar amount of pyrrole $(2.5 \mathrm{mmol}, 0.17 \mathrm{~mL})$ was carried out dropwise under stirring and heating $\left(\approx 120^{\circ} \mathrm{C}\right)$. After the complete addition (ca. $\left.3 \mathrm{~min}\right)$, the suspension was heated further to reflux temperature $\left(\approx 130^{\circ} \mathrm{C}\right)$ and maintained at this temperature for ca. $2 \mathrm{~h}$. The hot suspension was filtered through a sintered glass filter (a porosity of 4), and the resulting solid material was washed with tetrahydrofuran (THF) until no colored material was collected on the supernatant $(250 \mathrm{~mL})$. The volume of the solution was then reduced by rotoevaporation (enough volume to remove the added washing solvents). To induce precipitation, $n$-hexane (ca. $50 \mathrm{~mL}$ ) was added. The Erlenmeyer flask containing the statistical porphyrin mixture was left overnight in the refrigerator, at $4{ }^{\circ} \mathrm{C}$, and the deposited solid was collected by filtration and then purified by column chromatography using silica gel as a stationary phase, starting with $n$-hexane $/ \mathrm{CH}_{2} \mathrm{Cl}_{2}(1: 3)$ then increasing polarity using appropriate 
gradients of $n$-hexane $/ \mathrm{CH}_{2} \mathrm{Cl}_{2}$, then pure $\mathrm{CH}_{2} \mathrm{Cl}_{2}$, and finally $\mathrm{CH}_{2} \mathrm{Cl}_{2}$ / ethanol gradients if necessary (details in Supplementary Materials) to collect the second fraction (the target compound, in all cases). This fraction was then evaporated to dryness, and the resulting solid was dried under vacuum and weighed. Characterization data from Compounds 1 [53], 2 [52], 3 [59], and 4 [60] are in accordance with those in the literature. The characterization data for the new compounds are displayed below.

\subsubsection{5-(4-Acetylaminophenyl)-10,15,20-tris(2,6-difluorophenyl) Porphyrin (5)}

According to the general procedure, the benzaldehydes used were as follows: 4-acetylaminobenzaldehyde $(0.625 \mathrm{mmol}, 102 \mathrm{mg})$ and 2,6-difluorobenzaldehyde $(1.875 \mathrm{mmol}, 267 \mathrm{mg})$. Column chromatography was carried out using as eluent $n$-hexane $/ \mathrm{CH}_{2} \mathrm{Cl}_{2}(1: 3)$ to collect the first fraction $\left(\mathrm{A}_{4}\right.$ product) followed by ethanol $/ \mathrm{CH}_{2} \mathrm{Cl}_{2}$ (1:100) to collect Porphyrin 5. We obtained $78 \mathrm{mg}$ of Porphyrin 5 (16\% yield).

${ }^{1} \mathrm{H}-\mathrm{NMR}\left(\mathrm{CDCl}_{3}, 400 \mathrm{MHz}\right), \delta \mathrm{H}(\mathrm{ppm})=8.90-8.83(\mathrm{~m}, 8 \mathrm{H}, \beta-\mathrm{H}), 8.17(\mathrm{~d}, J=8.0 \mathrm{~Hz}, 2 \mathrm{H}, \mathrm{Ph}(\mathrm{Ac})-\mathrm{H})$, 7.90 (d, J = 8.0 Hz, 2H, Ph(Ac)-H), 7.89-7.76 (m, 3H, Ph-H), 7.49-7.36 (m, 6H, Ph-H), $2.36\left(\mathrm{~s}, 3 \mathrm{H}, \mathrm{CH}_{3}\right)$, -2.75 (s, 2H, NH). ${ }^{13} \mathrm{C}-\mathrm{NMR}\left(101 \mathrm{MHz}^{\mathrm{C}} \mathrm{CDCl}_{3}\right) \delta \mathrm{C}(\mathrm{ppm})=134.9,130.8,129.1,119.7,118.0,111.5$, 111.2, 24.6. ${ }^{19} \mathrm{~F}-\mathrm{NMR}\left(376.5 \mathrm{MHz}, \mathrm{CDCl}_{3}\right) \delta \mathrm{F}(\mathrm{ppm})=-108.2,-108.3$.

HRMS (ESI-FIA-TOF): Calcd. for $\mathrm{C}_{46} \mathrm{H}_{28} \mathrm{~F}_{6} \mathrm{~N}_{5} \mathrm{O}$ : 780.2193; Found $m / z=780.2202$ [M] ${ }^{+}$.

$\mathrm{UV}$-vis (toluene): $\lambda_{\max }, \mathrm{nm}\left(\varepsilon, \mathrm{M}^{-1} \cdot \mathrm{cm}^{-1}\right) 420\left(3.5 \times 10^{5}\right), 515\left(2.3 \times 10^{4}\right), 546\left(6.2 \times 10^{3}\right)$, $591\left(6.9 \times 10^{3}\right), 656\left(4.3 \times 10^{3}\right)$.

EA: Anal. Calcd for $\mathrm{C}_{46} \mathrm{H}_{28} \mathrm{~F}_{6} \mathrm{~N}_{5} \mathrm{O}$ : C: 70.86; H: 3.49; N: 8.98. Found: C: 70.87; H: 3.49; N: 8.97.

\subsubsection{5-(4-Acetylaminophenyl)-10,15,20-tris(2,6-dichlorophenyl) Porphyrin (6)}

According to the general procedure, the benzaldehydes used were as follows: 4-acetylaminobenzaldehyde (0.625 mmol, $102 \mathrm{mg})$ and 2,6-dichlorobenzaldehyde (1.875 mmol, $328 \mathrm{mg}$ ). Column chromatography was carried out using as eluent $n$-hexane $/ \mathrm{CH}_{2} \mathrm{Cl}_{2}$ (1:3) to collect the first fraction $\left(\mathrm{A}_{4}\right.$ product) followed by ethanol $/ \mathrm{CH}_{2} \mathrm{Cl}_{2}(1: 100)$ to collect Porphyrin 6. We obtained $71 \mathrm{mg}$ of Porphyrin 6 (13\% yield).

${ }^{1} \mathrm{H}-\mathrm{NMR}\left(400 \mathrm{MHz}, \mathrm{CDCl}_{3}\right), \delta \mathrm{H}(\mathrm{ppm})=8.85(\mathrm{~d}, J=4.5 \mathrm{~Hz}, 2 \mathrm{H}, \beta-\mathrm{H}), 8.66-8.62(\mathrm{~m}, 6 \mathrm{H}, \beta-\mathrm{H})$, $8.12(\mathrm{~d}, J=8.0 \mathrm{~Hz}, 2 \mathrm{H}, \mathrm{Ph}(\mathrm{Ac})-\mathrm{H}), 7.85$ (d, J = 7.9 Hz, 2H, Ph(Ac)-H), 7.79-7.65 (m, 9H, Ph-H), 2.31 (s, 3H, $\left.\mathrm{CH}_{3}\right),-2.56(\mathrm{~s}, 2 \mathrm{H}, \mathrm{NH}) .{ }^{13} \mathrm{C}-\mathrm{NMR}\left(101 \mathrm{MHz}, \mathrm{CDCl}_{3}\right) \delta \mathrm{C}(\mathrm{ppm})=135.1,131.2,129.2,124.6,119.7$, 117.6, 111.6, 111.4, 24.8.

MS (MALDI-TOF): $m / z=879.039[\mathrm{M}]^{+}$.

UV-vis (toluene): $\lambda_{\max }, \mathrm{nm}\left(\varepsilon, \mathrm{M}^{-1} \cdot \mathrm{cm}^{-1}\right) 420\left(3.6 \times 10^{5}\right), 514\left(2.3 \times 10^{4}\right), 545\left(6.1 \times 10^{3}\right)$, $591\left(6.9 \times 10^{3}\right), 656\left(4.4 \times 10^{3}\right)$.

EA: Anal. Calcd. for $\mathrm{C}_{46} \mathrm{H}_{27} \mathrm{~F}_{6} \mathrm{~N}_{5} \mathrm{O}$ : C: 62.89; H: 3.10; N: 7.97. Found: C: 62.85; H: 3.08; N: 7.99.

\section{Conclusions}

To conclude, the tested NaY zeolite acts as an efficient co-catalyst in the synthesis of unsymmetrical porphyrins in solution. The NaY (Lewis acidity of $520 \mathrm{mmol}$ pyridine per $\mathrm{g}$ ) also revealed high potential for the multi-gram scale preparation of unsymmetrical porphyrins, in similar or even higher yields than those reported, advantageously presenting a better, more cost-efficient rationale, along with a lower environmental impact, when compared to established methods, judging by its E Factor, a very important metric when designing environmentally sustainable methodologies. The performed approximate price analysis demonstrated that the "NaY method" is the most suitable method for the production of measurable quantities of unsymmetrical meso-aryl porphyrins, showing a quite favorable cost-to-efficiency ratio. We strongly believe that this type of developments in porphyrin chemistry is the necessary boost for a wider use of unsymmetrical meso-aryl substituted porphyrins. 
Supplementary Materials: The following are available online. Supplementary Materials: Characterization of NaY acidity, synthetic procedures for all compounds, characterization data, sustainability factors, and price evaluations.

Acknowledgments: The authors wish to thank FCT-Portugal (The Portuguese Foundation for Science and Technology) and FEDER (European Regional Development Fund) through the COMPETE Programme (Operational Programme for Competitiveness) for funding with PEst-OE/QUI/UI0313/2014, UID/QUI/00313/2013, and PTDC/QEQ-MED/3521/2014. NMR data was collected at the UC-NMR facility, supported by CENTRO-07-CT62FEDER-002012. C.A.H., S.M.A.P., M.J.F.C., and R.M.B.C. are grateful for their FCT grants SFRH/BD/84146/2012, SFRH/BPD/84619/2012, SFRH/BPD/99698/2014, and SFRH/BPD/100537/2014, respectively. L. D. D. is grateful for his Ph.D. grant 232620/2014-8/GDE from CNPq-Brazil.

Author Contributions: M.J.F.C. and M.M.P. conceived and designed the experiments; M.J.F.C., L.D.D., and C.A.H. performed the experiments; S.M.A.P. and R.M.B.C. performed sustainability and cost-efficiency calculations and analyzed the data; M.J.F.C., M.M.P., and R.M.B.C. wrote the paper.

Conflicts of Interest: The authors declare no conflict of interest. The founding sponsors had no role in the design of the study; in the collection, analyses, or interpretation of data; in the writing of the manuscript; or in the decision to publish the results.

\section{References}

1. Calvete, M.J.F.; Pinto, S.M.A.; Pereira, M.M.; Geraldes, C.F.G.C. Metal coordinated pyrrole-based macrocycles as contrast agents for magnetic resonance imaging technologies: Synthesis and applications. Coord. Chem. Rev. 2017, 333, 82-107. [CrossRef]

2. Pereira, M.M.; Arnaut, L.G.; Simoes, S.J.F.; Monteiro, C. Novel Derivatives of Porphyrin, Particularly Chlorins and/or Bacteriochlorins, and Uses Thereof in Photodynamic Therapy. US Patent WO/2006/053707, 26 June 2006.

3. Giuntini, F.; Boyle, R.; Sibrian-Vazquez, M.; Vicente, M.G.H. Porphyrin conjugates for cancer therapy. In Handbook of Porphyrin Science; Ferreira, G., Ed.; World Scientific Publishers: Singapore, 2013; Volume 27, pp. 303-416.

4. Sekkat, N.; Van den Bergh, H.; Nyokong, T.; Lange, N. Like a bolt from the blue: Phthalocyanines in biomedical optics. Molecules 2012, 17, 98-144. [CrossRef] [PubMed]

5. Calvete, M.J.F.; Simões, A.V.C.; Henriques, C.A.; Pinto, S.M.A.; Pereira, M.M. Tetrapyrrolic macrocycles: Potentialities in medical imaging technologies. Curr. Org. Synth. 2014, 11, 127-140. [CrossRef]

6. Simões, A.V.C.; Adamowicz, A.; Dabrowski, J.M.; Calvete, M.J.F.; Abreu, A.R.; Stochel, G.; Arnaut, L.G.; Pereira, M.M. Amphiphilic meso(sulfonate ester fluoroaryl)porphyrins: Refining the substituents of porphyrin derivatives for phototherapy and diagnostics. Tetrahedron 2012, 68, 8767-8772. [CrossRef]

7. Pinto, S.M.A.; Tome, V.A.; Calvete, M.J.F.; Pereira, M.M.; Burrows, H.D.; Cardoso, A.M.S.; Pallier, A.; Castro, M.M.C.A.; Toth, E.; Geraldes, C.F.G.C. The quest for biocompatible phthalocyanines for molecular imaging: Photophysics, relaxometry and cytotoxicity studies. J. Inorg. Biochem. 2016, 154, 50-59. [CrossRef] [PubMed]

8. $\quad$ Simões, A.V.C.; Pinto, S.M.A.; Calvete, M.J.F.; Gomes, C.M.F.; Ferreira, N.C.; Castelo-Branco, M.; Llop, J.; Pereira, M.M.; Abrunhosa, A.J. Synthesis of a new F-18 labeled porphyrin for potential application in positron emission tomography. In vivo imaging and cellular uptake. RSC Adv. 2015, 5, 99540-99546. [CrossRef]

9. Mansuy, D. A brief history of the contribution of metalloporphyrin models to cytochrome p450 chemistry and oxidation catalysis. CR Chim. 2007, 10, 392-413. [CrossRef]

10. Lu, H.J.; Zhang, X.P. Catalytic C-H functionalization by metalloporphyrins: Recent developments and future directions. Chem. Soc. Rev. 2011, 40, 1899-1909. [CrossRef] [PubMed]

11. Calvete, M.J.F.; Silva, M.; Pereira, M.M.; Burrows, H.D. Inorganic helping organic: Recent advances in catalytic heterogeneous oxidations by immobilised tetrapyrrolic macrocycles in micro and mesoporous supports. RSC Adv. 2013, 3, 22774-22789. [CrossRef]

12. Cuesta-Aluja, L.; Castilla, J.; Masdeu-Bulto, A.M.; Henriques, C.A.; Calvete, M.J.F.; Pereira, M.M. Halogenated meso-phenyl mn(iii) porphyrins as highly efficient catalysts for the synthesis of polycarbonates and cyclic carbonates using carbon dioxide and epoxides. J. Mol. Catal. A 2016, 423, 489-494. [CrossRef]

13. Tanaka, T.; Osuka, A. Conjugated porphyrin arrays: Synthesis, properties and applications for functional materials. Chem. Soc. Rev. 2015, 44, 943-969. [CrossRef] [PubMed]

14. Li, L.L.; Diau, E.W.G. Porphyrin-sensitized solar cells. Chem. Soc. Rev. 2013, 42, 291-304. [CrossRef] [PubMed] 
15. Dini, D.; Calvete, M.J.F.; Hanack, M. Nonlinear optical materials for the smart filtering of optical radiation. Chem. Rev. 2016, 116, 13043-13233. [CrossRef] [PubMed]

16. Calvete, M.J.F. Near-infrared absorbing organic materials with nonlinear transmission properties. Int. Rev. Phys. Chem. 2012, 31, 319-366. [CrossRef]

17. Pinto, S.M.A.; Neves, A.C.B.; Calvete, M.J.F.; Abreu, A.R.; Rosado, M.T.S.; Costa, T.; Burrows, H.D.; Pereira, M.M. Metalloporphyrin triads: Synthesis and photochemical characterization. J. Photochem. Photobiol. A 2012, 242, 59-66. [CrossRef]

18. Marques, A.T.; Pinto, S.M.A.; Monteiro, C.J.P.; de Melo, J.S.S.; Burrows, H.D.; Scherf, U.; Calvete, M.J.F.; Pereira, M.M. Energy transfer from fluorene-based conjugated polyelectrolytes to on-chain and self-assembled porphyrin units. J. Polym. Sci. Pol. Chem. 2012, 50, 1408-1417. [CrossRef]

19. Nardis, S. Synthetic Routes to Unsymmetrical Porphyrin. In Topics in Heterocyclic Chemistry; Paolesse, R., Ed.; Springer: Berlin/Heidelberg, Germany, 2014; Volume 33, pp. 203-229.

20. Henriques, C.A.; Fernandes, A.; Rossi, L.M.; Ribeiro, M.F.; Calvete, M.J.F.; Pereira, M.M. Biologically inspired and magnetically recoverable copper porphyrinic catalysts: A greener approach for oxidation of hydrocarbons with molecular oxygen. Adv. Funct. Mater. 2016, 26, 3359-3368. [CrossRef]

21. Nakagaki, S.; Ferreira, G.K.B.; Marcal, A.L.; Ciuffi, K.J. Metalloporphyrins immobilized on silica and modified silica as catalysts in heterogeneous processes. Curr. Org. Synth. 2014, 11, 67-88. [CrossRef]

22. Welch, C.; Archibald, S.J.; Boyle, R.W. Reductive amination-A convenient method for generating diverse, mono-functionalised 5,10,15,20-tetraphenyl porphyrins. Synthesis-Stuttgart 2009, 551-556.

23. Roales, J.; Pedrosa, J.M.; Guillen, M.G.; Lopes-Costa, T.; Pinto, S.M.A.; Calvete, M.J.F.; Pereira, M.M. Optical detection of amine vapors using zntriad porphyrin thin films. Sens. Actuators B Chem. 2015, 210, 28-35. [CrossRef]

24. Henriques, C.A.; Goncalves, N.P.F.; Abreu, A.R.; Calvete, M.J.F.; Pereira, M.M. Unsymmetrical porphyrins: The role of meso-substituents on their physical properties. J. Porphyr. Phthalocyanines 2012, 16, 290-296. [CrossRef]

25. Ooyama, Y.; Harima, Y. Photophysical and electrochemical properties, and molecular structures of organic dyes for dye-sensitized solar cells. ChemPhysChem 2012, 13, 4032-4080. [CrossRef] [PubMed]

26. Tome, J.P.C.; Neves, M.G.P.M.S.; Tome, A.C.; Cavaleiro, J.A.S.; Soncin, M.; Magaraggia, M.; Ferro, S.; Jori, G. Synthesis and antibacterial activity of new poly-s-lysine-porphyrin conjugates. J. Med. Chem. 2004, 47, 6649-6652. [CrossRef] [PubMed]

27. Harris, R.L.N.; Johnson, A.W.; Kay, I.T. A stepwise synthesis of unsymmetrical porphyrins. J. Chem. Soc. C 1966, 22-29. [CrossRef]

28. Lash, T.D. Porphyrin synthesis by the " $3+1$ " approach: New applications for an old methodology. Chem. Eur. J. 1996, 2, 1197-1200. [CrossRef]

29. Boudif, A.; Momenteau, M. A new convergent method for porphyrin synthesis based on a " $3+1$ " condensation. J. Chem. Soc. Perkin Trans. 1 1996, 1235-1242. [CrossRef]

30. Arsenault, G.P.; Bullock, E.; Macdonald, S.F. Pyrromethanes and porphyrins therefrom. J. Am. Chem. Soc. 1960, 82, 4384-4389. [CrossRef]

31. Bauer, V.J.; Clive, D.L.J.; Dolphin, D.; Paine, J.B.; Harris, F.L.; King, M.M.; Loder, J.; Wang, S.W.C.; Woodward, R.B. Sapphyrins-Novel aromatic pentapyrrolic macrocycles. J. Am. Chem. Soc. 1983, 105, 6429-6436. [CrossRef]

32. Sessler, J.L.; Johnson, M.R.; Lynch, V. Synthesis and crystal-structure of a novel tripyrrane-containing porphyrinogen-like macrocycle. J. Org. Chem. 1987, 52, 4394-4397. [CrossRef]

33. Sessler, J.L.; Genge, J.W.; Urbach, A.; Sanson, P. A “3+1” approach to monofuntionalized alkyl porphyrins. Synlett 1996, 187-188. [CrossRef]

34. Nguyen, L.T.; Senge, M.O.; Smith, K.M. Simple methodology for syntheses of porphyrins possessing multiple peripheral substituents with an element of symmetry. J. Org. Chem. 1996, 61, 998-1003. [CrossRef]

35. Lindsey, J.S. Synthetic routes to meso-patterned porphyrins. Accounts Chem. Res. 2010, 43, 300-311. [CrossRef] [PubMed]

36. Ryppa, C.; Senge, M.O.; Hatscher, S.S.; Kleinpeter, E.; Wacker, P.; Schilde, U.; Wiehe, A. Synthesis of monoand disubstituted porphyrins: A- and 5,10-a(2)-type systems. Chem. Eur. J. 2005, 11, 3427-3442. [CrossRef] [PubMed] 
37. Senge, M.O. Nucleophilic substitution as a tool for the synthesis of unsymmetrical porphyrins. Accounts Chem. Res. 2005, 38, 733-743. [CrossRef] [PubMed]

38. Zaidi, S.H.H.; Loewe, R.S.; Clark, B.A.; Jacob, M.J.; Lindsey, J.S. Nearly chromatography-free synthesis of the a(3)b-porphyrin 5-(4-hydroxymethylphenyl)-10,15,20-tri-p-tolylporphinatozinc(ii). Org. Process Res. Dev. 2006, 10, 304-314. [CrossRef]

39. Zaidi, S.H.H.; Fico, F.M.; Lindsey, J.S. Investigation of streamlined syntheses of porphyrins bearing distinct meso substituents. Org. Process Res. Dev. 2006, 10, 118-134. [CrossRef]

40. Silva, M.; Fernandes, A.; Bebiano, S.S.; Calvete, M.J.F.; Ribeiro, M.F.; Burrows, H.D.; Pereira, M.M. Size and ability do matter! Influence of acidity and pore size on the synthesis of hindered halogenated meso-phenyl porphyrins catalysed by porous solid oxides. Chem. Commun. 2014, 50, 6571-6573. [CrossRef] [PubMed]

41. Henriques, C.A.; Pinto, S.M.A.; Pina, J.; Serpa, C.; Fernandes, A.; Rossi, L.M.; Ribeiro, M.F.; Pereira, M.M.; Calvete, M.J.F. Cost-efficient method for unsymmetrical meso-aryl porphyrins and iron oxide-porphyrin hybrids prepared thereof. Dalton Trans. 2016, 45, 16211-16220. [CrossRef] [PubMed]

42. Henriques, C.A.; Pinto, S.M.A.; Canotilho, J.; Eusébio, M.E.S.; Calvete, M.J.F. Synthesis of low melting point porphyrins: A quest for new materials. J. Porphyr. Phthalocyanines 2016, 20, 843-854. [CrossRef]

43. Adler, A.D.; Longo, F.R.; Finarelli, J.D.; Goldmach, J.; Assour, J.; Korsakof, L. A simplified synthesis for meso-tetraphenylporphin. J. Org. Chem. 1967, 32, 476. [CrossRef]

44. Gonsalves, A.M.A.R.; Varejao, J.M.T.B.; Pereira, M.M. Some new aspects related to the synthesis of mesosubstituted porphyrins. J. Heterocyclic Chem. 1991, 28, 635-640. [CrossRef]

45. Lindsey, J.S.; Schreiman, I.C.; Hsu, H.C.; Kearney, P.C.; Marguerettaz, A.M. Rothemund and AdlerLongo reactions revisited-Synthesis of tetraphenylporphyrins under equilibrium conditions. J. Org. Chem. 1987, 52, 827-836. [CrossRef]

46. Shinoda, T.; Izumi, Y.; Onaka, M. Fsm-16-A recyclable mesoporous acid promoter for meso-tetraarylporphyrin synthesis. J. Chem. Soc. Chem. Comm. 1995, 1801-1802. [CrossRef]

47. Kishan, M.R.; Rani, V.R.; Murty, M.R.V.S.; Devi, P.S.; Kulkarni, S.J.; Raghavan, K.V. Synthesis of calixpyrroles and porphyrins over molecular sieve catalysts. J. Mol. Catal. A 2004, 223, 263-267. [CrossRef]

48. Petit, A.; Loupy, A.; Maillard, P.; Momenteau, M. Microwave irradiation in dry media - a new and easy method for synthesis of tetrapyrrolic compounds. Synth. Commun. 1992, 22, 1137-1142. [CrossRef]

49. Lucas, R.; Vergnaud, J.; Teste, K.; Zerrouki, R.; Sol, V.; Krausz, P. A facile and rapid iodine-catalyzed meso-tetraphenylporphyrin synthesis using microwave activation. Tetrahedron Lett. 2008, 49, 5537-5539. [CrossRef]

50. Nascimento, B.F.O.; Gonsalves, A.M.D.R.; Pineiro, M. Mno2 instead of quinones as selective oxidant of tetrapyrrolic macrocycles. Inorg. Chem. Commun. 2010, 13, 395-398. [CrossRef]

51. Henriques, C.A.; Pinto, S.M.A.; Aquino, G.L.B.; Pineiro, M.; Calvete, M.J.F.; Pereira, M.M. Ecofriendly porphyrin synthesis by using water under microwave irradiation. ChemSusChem 2014, 7, 2821-2824. [CrossRef] [PubMed]

52. Henriques, C.A.; Pinto, S.M.A.; Pineiro, M.; Canotilho, J.; Eusébio, M.E.S.; Pereira, M.M.; Calvete, M.J.F. Solventless metallation of low melting porphyrins synthesized by the water/microwave method. RSC Adv. 2015, 5, 64916-64924. [CrossRef]

53. Adler, A.D.; Shergali, W.; Longo, F.R. Mechanistic investigations of porphyrin syntheses. I. Preliminary studies on ms-tetraphenylporphin. J. Am. Chem. Soc. 1964, 86, 3145-3149. [CrossRef]

54. Tome, J.P.C.; Neves, M.G.P.M.S.; Tome, A.C.; Cavaleiro, J.A.S.; Mendonça, A.F.; Pegado, L.S.N.; Duarte, R.; Valdeira, M.L. Synthesis of glycoporphyrin derivatives and their antiviral activity against herpes simplex virus types 1 and 2. Bioorg. Med. Chem. 2005, 13, 3878-3888. [CrossRef] [PubMed]

55. Cairon, O. Construction of quantitative molecular isotherms from ftir analysis of dinitrogen (n-2) adsorption on a microporous nay zeolite. Phys. Chem. Chem. Phys. 2012, 14, 12083-12085. [CrossRef] [PubMed]

56. Green chemistry metrics. In Measuring and Monitoring Sustainable Processes; Lapkin, A., Constable, D., Eds.; Wiley-Blackwell Publishing: Singapore, 2009.

57. Sheldon, R.A. Catalysis: The key to waste minimization. J. Chem. Technol. Biotechnol. 1997, 68, 381-388. [CrossRef]

58. Lindsey, J.S.; Maccrum, K.A.; Tyhonas, J.S.; Chuang, Y.Y. Investigation of a synthesis of meso-porphyrins employing high-concentration conditions and an electron-transport chain for aerobic oxidation. J. Org. Chem. 1994, 59, 579-587. [CrossRef] 
59. Lipshutz, B.H.; Isley, N.A.; Fennewald, J.C.; Slack, E.D. On the way towards greener transition-metal-catalyzed processes as quantified by e factors. Angew. Chem. Int. Ed. 2013, 52, 10952-10958. [CrossRef] [PubMed]

60. Matile, S.; Berova, N.; Nakanishi, K.; Fleischhauer, J.; Woody, R.W. Structural studies by exciton coupled circular dichroism over a large distance: Porphyrin derivatives of steroids, dimeric steroids, and brevetoxin b. J. Am. Chem. Soc. 1996, 118, 5198-5206. [CrossRef]

61. Kon, H.; Nagata, T. Syntheses, properties, and photoreactions of the hybrid molecules consisting of a coii mononuclear complex and porphyrins. Chem. Eur. J. 2012, 18, 1781-1788. [CrossRef] [PubMed]

62. Chen, H.; Viel, S.; Ziarelli, F.; Peng, L. F-19 NMR: A valuable tool for studying biological events. Chem. Soc. Rev. 2013, 42, 7971-7982. [CrossRef] [PubMed]

63. Goslinski, T.; Piskorz, J. Fluorinated porphyrinoids and their biomedical applications. J. Photochem. Photobiol. C 2011, 12, 304-321. [CrossRef]

64. Pandey, S.K.; Gryshuk, A.L.; Graham, A.; Ohkubo, K.; Fukuzumi, S.; Dobhal, M.P.; Zheng, G.; Ou, Z.P.; Zhan, R.Q.; Kadish, K.M.; et al. Fluorinated photosensitizers: Synthesis, photophysical, electrochemical, intracellular localization, in vitro photosensitizing efficacy and determination of tumor-uptake by f-19 in vivo nmr spectroscopy. Tetrahedron 2003, 59, 10059-10073. [CrossRef]

65. Pires, S.M.G.; Simões, M.M.Q.; Santos, I.C.M.S.; Rebelo, S.L.H.; Pereira, M.M.; Neves, M.G.P.M.S.; Cavaleiro, J.A.S. Biomimetic oxidation of organosulfur compounds with hydrogen peroxide catalyzed by manganese porphyrins. Appl. Catal. A Gen. 2012, 439, 51-56. [CrossRef]

Sample Availability: Samples of the compounds 1-6 are available from the authors.

(C) 2017 by the authors. Licensee MDPI, Basel, Switzerland. This article is an open access article distributed under the terms and conditions of the Creative Commons Attribution (CC BY) license (http:/ / creativecommons.org/licenses/by/4.0/). 